The Philosophical Journal of Conflict and Violence

Vol. II, Issue $1 / 2018$

(C) The Authors 2018

Available online at http://trivent-publishing.eu/

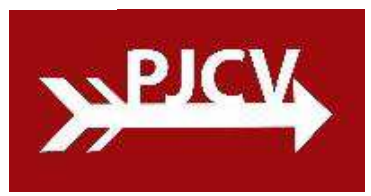

\title{
Natality and Exposure: A Philosophical Account of the Harm of Sexual Violence
}

\author{
Sarah Lafford \\ Staffordshire University, United Kingdom
}

\begin{abstract}
From an ontological foundation of natality, drawing from Hannab Arendt and Adriana Cavarero, this paper concludes that sexual violence uniquely undermines being-in-theworld and being-in-the-world-with-others. The framework of natality is not usually directly applied to sexual violence. Natality roots us ontologically in birth, beginnings and relationality. While the promise of the natal inclines the subject outwards, towards others, the horror of rape freezes victims in objectification, exploits exposure and entangles victims physically and psychically with their abuser. Sexual violence is the very antitheses to the promise of the natal.
\end{abstract}

Keywords: Hannah Arendt; Judith Butler; Adriana Cavarero; Natality; Sexual violence; Relationality; Vulnerability.

DOI: 10.22618/TP.PJCV.20182.1.171004

\section{TRIVENT}

The PJCV Journal is published by Trivent Publishing

This is an Open Access article distributed in accordance with the Creative Commons Attribution Non Commercial (CC-BY-NC-ND 4.0) license, which permits others to copy or share the article, provided original work is properly cited and that this is not done for commercial purposes. Users may not remix, transform, or build upon the material and may not distribute the modified material (http:/ / creativecommons.org/ licenses/by-nc/4.0/) 


\title{
Natality and Exposure: A Philosophical Account of the Harm of Sexual Violence
}

\author{
Sarah Lafford \\ Staffordshire University, United Kingdom
}

\begin{abstract}
From an ontological foundation of natality, drawing from Hannab Arendt and Adriana Cavarero, this paper concludes that sexual violence uniquely undermines being-in-theworld and being-in-the-world-with-others. The framework of natality is not usually directly applied to sexual violence. Natality roots us ontologically in birth, beginnings and relationality. While the promise of the natal inclines the subject outwards, towards others, the horror of rape freezes victims in objectification, exploits exposure and entangles victims physically and psychically with their abuser. Sexual violence is the very antitheses to the promise of the natal.
\end{abstract}

Keywords: Hannah Arendt; Judith Butler; Adriana Cavarero; Natality; Sexual violence; Relationality; Vulnerability.

\section{Introduction}

If philosophy is concerned with the way we live in the world, human subjectivity and relations to others, then rape and sexual violence ${ }^{1}$ must be thoroughly analysed. Sexual violence against women and girls has been called a pandemic. ${ }^{2}$ Despite this, sexual violence has evaded adequate political and philosophical analysis, being consigned instead to the domestic and private sphere.

In this paper, I am concerned with philosophically analysing the harm of sexual violence for the victimised subject. ${ }^{3}$ I will be drawing from Hannah Arendt's radical framework of natality, where our physical and political birth into the world, our capacity to begin, is the foundation for our "being-in-the-world" and "being-in-the-world-with-others." ${ }^{4}$ I will also draw on Adriana Cavarero's development of natality, as she makes important developments to the concept that locate and emphasise the maternal witness. I will refer to Arendt and Cavarero's philosophies of beginnings, relationality and vulnerability as the "natal turn."

\footnotetext{
${ }^{1}$ I largely use the term sexual violence throughout to signify rape and the many other types of sexual abuse.

2 The World Health Organisation in 2015 described sexual violence as a global public health pandemic, with one in three women and girls experiencing some form of rape and sexual abuse.

${ }_{3}^{3}$ People of any gender can, and are, victimised by sexual violence. Equally, people of any gender can be, and are, perpetrators of sexual violence. This project though will refer largely, but not solely, to sexual violence perpetrated by men to women.

${ }^{4}$ I will use this Heideggerian terminology throughout as a useful way of naming that specific type of being that is human, rooted in the world with others.
} 
After outlining natality, and also plurality, I will build on Arendt and Cavarero's explicit concern with types of non-sexual violence, namely totalitarianism ${ }^{5}$ (Arendt) and "horrorism" (Cavarero). Despite the focus on other types of violence, their philosophies of natality resonate profoundly with the specificity of sexual violence. I will look closely at the trauma of sexual violence and the ways it undermines our natal being-in-the-world and being-in-the-world-with-others and argue that this harm is particular to sexual violence.

\section{Arendt on Natality}

Arendt's conceptualisation of human existence, of being-in-the-world, radically rejects the ideal "I" that transcends one's outward appearance in the world. For Arendt, the question of who I am is answered in my public appearance, the way I act in the world and how I am seen. Action and appearance are therefore fundamental to human life, and both are rooted in beginnings, creation, or adding something new to the world.

In the concluding chapter of Origins of Totalitarianism, Arendt states that each new birth is a beginning; a beginning that changes the world and delivers "promise" and that is the "supreme capacity of man...identical with man's freedom." Natality continues to ground her work on the human condition and her later investigation of thinking and willing. Arendt did not treat natality as a new metaphysics, but rather part of a political turn in perspective that firmly focuses on the political promise of each and every person. There is a clear twofold nature to natality; primary natality is one's physical birth, their first entrance into the world, the beginning of somebody "who is a beginner himself." we are each an assertion of newness. Secondary natality is one's public and political appearance in the world; to appear is to "act" in the world, to actualise our condition as a beginner, to make real our capacity to begin. ${ }^{8}$ I will refer throughout to primary/physical natality and secondary/political natality. It is worth spending more time unpicking what Arendt means by a second, political, birth.

While secondary natality happens after physical natality (we have to first enter the world as a beginner, in order to actualise this capacity to begin), it is not secondary to physical natality in terms of conceptual weight. Rather, appearance in the public realm is the very way that individuals distinguish themselves as a "who." Without public appearance an individual is merely identified by the "what" of the category of human. By acting, by realising one's natal capacity, humans "distinguish themselves," forming their selfhood, their "who-ness". Action moves us outwards, placing us in the realm of publicness, and away from the shadowy realm of privacy (where we are not witnessed). To act in the realm of publicness is to have "worldliness;" that is, to be political, to be public, to be seen.

Arendt's development of the two expressions of natality can be conceptualised as a call and response exchange. The first birth where we come into the world poses a question, it

\footnotetext{
5 Sexual violence was a common occurrence in Nazi concentration camps but does not occur in Arendt's writings on totalitarianism.

${ }^{6}$ Hannah Arendt, Origins of Totalitarianism (Oxford: Benediction Classics, 2009), 479.

${ }^{7}$ Hannah Arendt, The Human Condition, $2^{\text {nd }}$ ed (Chicago: University of

Chicago Press, 1998), 177.

${ }^{8}$ Bowen-Moore identifies a third natality, what she calls theoretical natality, where each thought is an insertion of newness into the realm of human thought. I do not see the benefit of theoretically separating the realisation of our capacity to act anew from our capacity to think anew; in fact, this distinction regresses the natal framework in the direction of idealism. If being and appearance are one and the same, then our capacity for action and our capacity for thought are existentially equiprimordial.

${ }^{9}$ Hannah Arendt, The Human Condition, 176.
} 
presents a new beginner, they are a beginner because they are characterised by their capacity to insert further newness into the world, yet the nature of that newness is unknowable. The question of the new beginner is answered with secondary natality, where public action defines the who-ness of the beginner and actualises their capacity to begin. To be born, but to never appear and act publicly is to leave the question posed by primary birth unanswered; it would be a life unknowable, a life unlived.

That natality is central to being-in-the-world does not stabilise it as a dependable certainty. While mortality is certain (it is certain that all lives will end), being born, and "birthing" action in the world are uncertain, and there lies the dynamic potentiality, and also the fragility of human existence. It is not only possible to not physically begin (I might very well not have been born or failed to have survived infancy); we can fail to assert newness in the public realm.

Arendt's natality dismisses the "popular belief in a 'strong man' who, isolated against others, owes his strength to his being alone." 10 To truly be-in-the-world, others who share uniqueness in common must witness us. To be-in-the-world one must be-with-others. Arendt's ontology of natality is therefore thoroughly relational.

I have referred to the importance of being "seen" or "witnessed" for Arendt, and this is understood through the concept of plurality; the foundation for the "web of human relations"11. Plurality is essentially tied to natality, as it is only in being witnessed that we can say we have acted in the public sphere. For Arendt, the pleasure derived from being witnessed in public is singular, it cannot be replicated elsewhere. Arendt refers to this pleasure as an "urge towards self-display," 12 a desire to appear before others.

Plurality is the basis of our human relations but should not be mistaken as simply an expression of relationality. Arendt does far more with her theory of plurality than say that all beings are connected and related to one another. Plurality has the "twofold character of equality and distinction"13 the world is that which is shared amongst us all as humans, and because we are all different humans, we have in common a condition of difference. There can be no new being who is not wholly different and singular, yet this difference does not alienate us from one another, for this very difference is that which we all hold in common. The one assertion about all others I can hold for certain is that they are all singular, different beings. What shape this uniqueness takes, the who-ness of this difference, is only revealed through action.

Arendt's plurality rejects universality for difference and particularity. If who-ness is revealed through action, and action is only action when it is witnessed, it follows that whoness is thoroughly public. The who-ness of an individual is not intimately nurtured, and it is neither hidden from others nor owned by a singular being. One's who-ness has to be witnessed in order for that who-ness to be. But action is not the emerging of who-ness from the individual to the public, action does not transport who-ness from private contemplation into public witnessing, rather who-ness is created in public witnessing, in being seen.

A consequence of plurality is that we are all vulnerable to others. We are of course vulnerable to harm that might be inflicted upon us by others, but another important way we are all vulnerable in plurality is not being witnessed or being forgotten. As part of the world, we are meant to be "seen, heard, touched, tasted and smelled," 14 we have an urge towards

\footnotetext{
${ }^{10}$ Ibid. 188.

${ }^{11}$ Ibid., 183.

${ }^{12}$ Hannah Arendt, The Life of the Mind Volumes 1 \& 2 (London: Secker \&Warburg, 1978), 21.

${ }^{13}$ Hannah Arendt, The Human Condition, 175.

${ }^{14}$ Hannah Arendt, The Life of the Mind, 19.
} 
appearance and that appearance would be meaningless without a spectator. It would be meaningless firstly because, as we have seen, public witnessing creates who-ness, and secondly, without witness, actions, and actors, would be forgotten. To remedy forgetfulness, Arendt emphasises the importance of speech and storytelling. Speech through language is the way that we articulate the meaning of action. When action is translated into speech, it forms part of a story, a story that discloses the who-ness of my whole life. Arendt tells us "action reveals itself fully only to the storyteller, that is, to the backward glance of the historian, who indeed always knows better what it was all about than the participants." $15 \mathrm{We}$ reveal ourselves contemporaneously in action, but only others can disclose our whole story, in remembrance. So, though stories are the results of an individual's own actions, "it is not the actor but the storyteller who perceives and 'makes' the story" ${ }^{16}$. And this story can only be told in full after death. In storytelling we each seek remembrance, to be remembered after our lives are over and have that story take its place in the world. Arendt's consideration of remembrance and storytelling has since inspired much, largely feminist, work on the relational power of narration, biography and stories, including Cavarero.

\section{Cavarero on Natality}

Like Arendt, Cavarero treats as ontologically foundational the relationality of natal beginners, which she characterises as "inclination" towards others. But Cavarero's natal philosophy is a critical development. Arendt has been accused of abstracting natality too far. Birth is fleshy and immediate; to remove fleshiness from natality risks sacrificing the physical lived experience for the conceptual realm, a risk at odds with the natal turn. Cavarero responds to this critique by reuniting natality with the body, and she does this by examining the primary natal moment.

Cavarero develops natality by embodying it in the flesh and asserting the maternal in the primary natal scene. In birth "one is not alone but in a duo; the mother and the one who is born." 17 Though the natal invokes the reproductive capacity of the, usually, female body, Arendt did not take a gendered approach to natality. Cavarero criticises the absence of the maternal witness in Arendt's primary natality. This absence, Cavarero argues, results in an "abstract and cold"18 natal scene and a beginner characterised by "inhuman loneliness"19 where birth, rather than coming from another is a "coming from nothing." 20

In contrast, by asserting the natal scene as occupied by two, the new-born, far from inhuman or lonely, has "already 'started' inside the mother: it is generated by the female who has already been generated by a $\mathrm{m} /$ other, and so on ad infinitum in a sequence... of past mothers." 21 Not only does Cavarero locate the maternal, she affords the maternal privilege, as the primary scene of relationality. From our first moment our being depends on the presence of others, the maternal attachment signifies the beginning of our relational connections with others.

Cavarero's work sharpens the feminism of the natal turn, asserting both the body and the gendered primary witnessing of our natal appearance. By allowing beginnings to "come from nothing," Arendt can be said to not only strip natality of its maternity, but also of its

\footnotetext{
${ }^{15}$ Hannah Arendt, The Human Condition, 192.

16 Ibid. 192.

${ }^{17}$ Adriana Cavarero, In Spite of Plato: a Feminist Rewriting of Ancient Philosophy (Cambridge: Polity Press, 1995), 82.

18 Adriana Cavarero, Inclinations: A Critique of Rectitude (Stanford: Stanford University Press, 2016), 115.

${ }^{19}$ Ibid., 120.

${ }^{20}$ Adriana Cavarero, In Spite of Plato, 6.

${ }^{21}$ Ibid., 82.
} 
femininity. By re-painting the natal scene as a feminine, maternal scene, Cavarero conceptually prioritises that moment that is so closely tied to the private sphere of family and domesticity, consequently, action and beginnings "cease to be confined to the political realm... and Arendt's sharp public/private contrast is broken down." 22 This critique of Arendt is, I believe, born from Arendt's debt to ancient political thought that disregarded the private in favour of the polis (public space for political action and speech). But it is worth noting that Arendt herself acknowledged that the family is the primary "we." 23 Suggesting that the family is capable of carving out some who-ness, albeit to a lesser extent than the political, singular self.

By untangling natality from Arendt's abstraction, Cavarero more clearly locates the specificity of the being that is born in primary natality. Put another way, an embodied and maternal natality asserts singularity; I am that being, and no other. To come from nothing bears the risk of universalising natal beings, where they might be rendered superfluous. If each birth is particular, then birth individualises us. And so while Arendt claims that political natality, in the form of our actions in the world, individualises us, Cavarero locates this singularity first in primary natality.

Like Arendt, remembrance and storytelling are vital to relationality for Cavarero. We appear in action and speech, and by being exposable we are also "a narratable self with a unique story." 24 Our actions are given meaning through speech, more precisely, through narration. Because of the urge towards self-display, we each want to hear our story, told by others as biography, in life. Our selfhood is then "rendered palpable" 25 in storytelling. It follows therefore, that as soon as one appears, one's story begins to be told, and one's story begins to be concretised. Is this not overwhelming for the beginner thrust into the world? Does the weight of each action's consequences not bear heavy on our concern for our individual narrative? The natal turn responds yes; appearance is vulnerability.

\section{Vulnerability, Violence, and Horrorism}

Arendt and Cavarero recognise the vulnerability inherent in natal beginnings and plurality. Vulnerability is not merely a consequence of the necessity of appearance but should be understood as a paradigm for human appearance and relations. Judith Butler does this when she reframes appearance as exposure. To be witnessed, Butler writes, is to be thoroughly attached to others, and for this reason, losing witnesses is to lose attachments, to lose relational being. This attachment also puts us at risk of violence; "the skin and flesh expose us to the gaze of others, but also to touch." 26 To appear, and to be witnessed, is really exposure, stark, unmitigated and vulnerable. Vulnerability, for Butler, is much more than a mere consequence of certain kinds of appearances. By being-in-the-world, we are all always exposed to others and the unknowability of the world. We cannot "will away this vulnerability. We must attend to it, even abide by it." ${ }^{27}$ This vulnerability is the lens through which all being-in-the-world and being-with-others must be understood.

Butler's centring of vulnerability to the natal turn affirms human interdependence, but she adds that it is important for legal and social purposes to enforce individual bodily autonomy. In other words, this interdependence and rejection of the notion of an ideal

22 Alison Stone, "Natality and mortality: rethinking death with Cavarero", Continental Philosophy Review 43, no. 3 (2010): 355, https://doi.org/10.1007/s11007-010-9148-3 (accessed January 5, 2018).

${ }^{23}$ Hannah Arendt does this in The Life of the Mind.

24 Adriana Cavarero, In Spite of Plato, 34.

25 Adriana Cavarero, Relating Narratives: Stories and Selfhood. (London: Routledge, 2000), 13.

26 Judith Butler, Precarious Life (London: Verso, 2004), 29.

27 Ibid., 29. 
inner I, does not equate to an eschewing of individual political rights. By struggling for individual autonomy whilst recognising relational vulnerability, we create community, where we are all alike in our vulnerability yet "having this condition separately and so having in common a condition that cannot be thought without difference." 28 Vulnerability is lived uniquely by each natal beginner, and yet we all share this condition of difference. Vulnerability, therefore, asserts plurality.

According to Cavarero, Arendt does not go deep enough in her use of vulnerability in natality because "she has little interest in the body." 29 In Horrorism, Cavarero conceptualises vulnerability as attached to our bodies, a feature that "accompanies us." 30 In Inclinations, vulnerability is less an attachment or accompaniment that we drag along beside ourselves, it is not a feeling or an experience, but it is our origin, an ontological necessity. We cannot be, without being vulnerable. Cavarero says emphasising vulnerability is "to think relation itself as originary and constitutive, as an essential dimension of the human" 31 . And this assertion is no abstraction from lived experience; rather it is embedded in concrete, and often imbalanced, lived situations. ${ }^{32}$

Natality is an outward-facing, thoroughly relational and optimistic theoretical framework in its emphasis on beginnings, publicness and inclination towards others. But as Arendt has suggested, and Cavarero and Butler have emphasised, vulnerability is necessary to a philosophy of natality. We are all existentially vulnerable to ourselves; our insertion of newness into the world is that which we can never fully know nor take back. We are all existentially vulnerable to others; the specificity of our natal selves is fragile to remembrance and our exposure to others is vulnerable to violence and harm. Natality also asserts that there is no untouchable private self, immune to the world. If we are all exposed, it is important to analyse what happens to the beginner when this exposure, this vulnerability, is exploited.

Arendt and Cavarero (and also Butler) have an explicit concern with violence in their work. The commitment each of these thinkers has to questions of violence solidifies the importance of examining sexual violence with a theoretical grounding in natality. In the wake of $20^{\text {th }}$ century totalitarian violence, in particular Nazi death camps, Arendt wrote that those who have experienced abuse are exposed to the very edges of human potentiality. Totalitarianism is, for Arendt, the antithesis of political natality. The consequence of the sustained violence of the death camps was the destroying of human uniqueness, where the condition of difference central to plurality is undermined. The optimistic potentiality of natality is reversed; in sustained violence we are exposed to what humans are capable of doing to one another and the irreversibility of even the most harmful of actions. It is not the killing of people, even on the scale committed in the death camps, that characterises what Arendt calls "radical evil,"33 rather it is this very exposure to the depths of human possibility. Extreme pain is an incommunicable experience, an experience that cannot be translated into a shared public appearance. For this reason, the experience of abuse and suffering remain private, unspoken, thereby forgotten. Within these depths of human

\footnotetext{
28 Ibid., 27.

${ }^{29}$ Adriana Cavarero. Horrorism: Naming Contemporary Violence. (New York: Colombia University Press, 2008), 20.

30 Ibid. 20.

31 Adriana Cavarero, Inclinations: A Critique of Rectitude. (Stanford: Stanford University Press, 2016$), 13$.

32 Here, Cavarero directly references Butler's work in Precarious Life, where the lived experience of violence and mourning are the starting point for an existential understanding of vulnerability.

33 Hannah Arendt, Origins of Totalitarianism, 459.
} 
possibility, "human togetherness" is lost, "words reveal nothing," 34 so the who of the person is stripped, leaving only the what of victims, prisoners, and bodies.

Cavarero's theory of horrorism is an account of violence that I suggest connects closely with the particularity of sexual violence. Horrorism is the name Cavarero affords violence that offends us at an ontological level, identified through an analysis of contemporary terrorism, torture in Abu Ghraib and the holocaust as well as mythology (Medusa and Medea). In Horrorism, Cavarero affords primacy to the victims of abuse, where an understanding of the pain of abuse should be privileged over a morbid fascination with the pleasure of causing pain. Cavarero's view of violence contains similarities to Arendt's writings on totalitarianism. Like Arendt, Cavarero identifies a dismantling of relationality in human suffering, "each victim is affected on its own." 35 Cavarero identifies this isolation in the "paralysis" 36 of horrorism, where we do not fight or flee for survival but are frozen into an object of suffering. And just as Arendt wrote that speech is denied in pain, Cavarero insists that we still lack an adequate language to talk about horror.

There are two outcomes, closely connected, to the harm of horrorism that are worth emphasising. In horrorism, victims are no longer vulnerable, and no longer unique. In terror we fear death, but in horror "killing would be too little;" 37 horrorism's end is not to cause death, rather to produce "victims who can no longer suffer." 38 Horror is located in a place of suffering victims are taken to that is beyond vulnerability. As I have outlined, vulnerability is foundational to being-in-the-world-with-others, it is the paradigm of human experience. The acute harm of horror therefore is not simply the reminder of this condition of vulnerability; rather it is the very dismantling of that condition. Victims are rendered invulnerable, suffering so much they can suffer no more. This existential place beyond vulnerability, I name endurance.

By losing their vulnerability, victims lose their uniqueness. Cavarero tells us that what is at stake here is "the human condition itself, as incarnated in the singularity of vulnerable bodies." 39 Endurance is a process of "nullifying" 40 humans, not killing them but reducing their subjectivity to frozen object, the "body undone," 41 undone from its who-ness. The picture Cavarero paints of victims frozen in their endurance of suffering, a suffering that is existentially beyond vulnerability, and bodies "undone" will be taken forward in my analysis of the harm of sexual violence.

Natality signifies our capacity to begin, and to appear in the world. I will set out the ways that the trauma of sexual violence undermines our natal being-in-the-world, or our capacity to act as beginners. I will first address the undermining of political or secondary natality via the reduction of victims to mere objects and the reduction of one's worldly possibilities to simple endurance. The particularity of physical entanglement and bodily betrayal in sexual violence further displaces victims from their place in the world and erodes intentionality. I will then move to the dismantling of primary natality via forced pregnancy.

\footnotetext{
${ }^{34}$ Hannah Arendt, The Human Condition, 180.

35 Cavarero, Horrorism, 7.

36 Ibid., 7.

37 Ibid., 8.

38 Ibid., 35

39 Ibid., 8.

40 Ibid., 9 .

41 Ibid., 9 .
} 


\section{The Harm of Sexual Violence on Being-in-the-World}

$\mathrm{Du}$ Toit's philosophical interpretation of first-person accounts of rape ${ }^{42}$ offers important theoretical investigation into the harm of sexual violence. I will reference some of her theory, and the accounts that she uses, in my own analysis. It is worth noting a limitation to Du Toit's work. Du Toit correctly critiques the commonly assumed opposition of "mere" or "simple" rape versus that of "aggravated" rape, where there is serious physical injury in addition to the sexual abuse. Mere rape is wrongfully deemed less harmful than aggravated rape. However, Du Toit almost entirely devotes her analysis to so called "aggravated" rapes where there is extreme physical violence or even attempted murder, reproducing the very myth she criticises. If we are to commit to the premise that the harm of rape affects victims very being-in-the-world, it is important to reject a ranking of seriousness based on the type of force used. There is a kind of harm integral to all sexual violence, and any physical harm is an additional harm. I mitigate this limitation to Du Toit's work by drawing from accounts of rape where the force of sexual violence is not only physical violence but also coercion, exploitation or the threat of (but not the act of) physical violence.

Du Toit begins her analysis of sexual violence by describing this particular harm as "spirit injury," which is a loss of "one's sense of self in relation to one's world." 43 The traumatised subject is left to question how she occupies a space in the world and how she comports herself as an individual being. Using Arendtian language, the victim asks how she might continue to possess worldliness. And this is true of all types of sexual violence; there is a common thread linking the experiences of victims and that is the "severe challenge to their subjective identities." 44 The result of this loss of selfhood is a process of dehumanisation, where the victim is reduced to "passive and powerless object." 45 This objectification is powerfully illustrated by Raine's testimony of rape, where she describes herself in the scene of her rape, tied to a bed with tape, as a living "corpse", and even a "trussed chicken about to go in the oven." ${ }^{46}$ By binding her body to the bed and raping her over many hours, the abuser reduced Raine to mere thinghood. Her single possibility in the world was to endure abuse. Without agency, and without a multitude of possibilities in the world to act upon, she became a what and no longer a who. Like in horrorism, she becomes fully available object, frozen, static, at the mercy of others. Raine's world was thus defined by the limits of her body as object. This reduction of her world meant she was no longer worldly in the Arendtian, political sense. Her freedom to insert new beginnings, to act, was bound to the limits of her body as object.

For Du Toit and also Cahill ${ }^{47}$ this experience of objectification in sexual violence ripples out beyond the event of rape and is felt by all women as those most vulnerable to rape. Cahill claims the way feminine bodies are objectified is as that of "pre-victim." 48 To be objectified in such a way, Cahill writes, is to have the limits of one's world tightened, just as Raine's were by being physically bound and left to endure. All "pre-victims" are bound by a "limited, individual safety zone which determines the smallness of a woman's step, the gathering in of her sitting body, and the daintiness of her gestures" that mirror the

\footnotetext{
${ }^{42}$ Louise Du Toit, A Philosophical Investigation of Rape: The Making and Unmaking of the Feminine Self (London: Routledge, 2009).

43 Ibid., 79.

44 Ibid., 65.

45 Ibid., 81

46 Ibid., 81-82.

47 Ann Cahill, "Foucault, Rape and the Construction of the Feminine Body", Hypatia 15, no. 1 (2000): pp. 43-63, http://doi.org/10.1111/j.1527-2001.2000.tb01079.x (accessed January 24, 2018).

48 Ibid., 56.
} 
"hampering of her mobility."49

To be left only as an object of endurance strips the natal power of one's being-in-theworld. As living corpse, her consent is not sought nor needed, her will to appear in the world unimportant and unseen. She has been excluded from the domain of beginner, the domain of actor. Rather than beginning, inserting action into the world, she only endures. No longer a beginner, the traumatised subject is consigned to a realm characterised by what Arendt calls "non-acting." 50

Physical proximity between victims and perpetrators is a central characteristic of nearly all forms of sexual violence. I will refer to that proximity as "entanglement". Entanglement undermines victims' being-in-the-world as their place in the world is no longer resolutely their own and their appearance is distorted from their intention. Cavarero refers to the "body undone;" 51 I will refer to the body displaced, as I am concerned with one's place in the world, the capacity for victims to be-in-the-world, thereby taking their place in the world amongst others. There are two elements to this entanglement, first the individual displacement of being entangled with the body of the abuser, and second the behaviour of one's own body that betrays one's intended appearance.

Describing horrorism, Cavarero writes how in mass killings in the form of suicide bombings "the limbs of victims and perpetrators frequently get mixed up." 52 In the scene of a bombing, the remains of the attacker and the victims are thrown together, with no clear distinction. She paints a nightmarish scene of dismemberment, displacement and physical entanglement, where the "body undone...loses its individuality" 53. Sexual violence, most often, involves the bodies of victim and perpetrator entangled via limbs and skin on skin contact, but also bodily fluids, semen, saliva and blood, that can lead to long-lasting physical changes, such as infections and pregnancy. The individuality of the victim becomes lost as her body is wrapped in the body of her abuser, as his body is inside her. Rather than being inclined towards others, she is no longer individually placed in the world; she is displaced as part of some other, and he is a part of her. This entanglement is not a singular event, but a new mode of embodiment; traces of him are left on and in her, and traces of her on and in him. As a consequence, her place in the world is no longer her own, she is not in-the-world as she once was.

$\mathrm{Du}$ Toit states that one has a strong place in the world "if her body mainly supports rather than obstructs her subjective, intentional existence in the world." 54 A second way that victims are entangled with their abusers is via, what I call, bodily betrayal. This betrayal obstructs her intentional appearance, the way she chooses to be-in-the-world. Victims report their bodies betraying their intentions whilst they are being subjected to abuse. Examples of this include freezing up rather than fighting or fleeing,

...my body seemed to freeze over. A million thoughts rushed through my head and then stopped, and my mind started drifting somewhere else, somewhere safer, as I lay in the back of his car stiff and silent. ${ }^{55}$

And physically responding to bodily stimulation,

\footnotetext{
49 Ibid., 55.

${ }^{50}$ Hannah Arendt, The Human Condition, 234.

51 Adriana Cavarero, Horrorism, 9.

52 Ibid., 9.

53 Ibid., 8.

${ }^{54}$ Louise Du Toit, A Philosophical Investigation of Rape, 60.

55 Jackie Hong, "Why Victims Freeze Up During Sexual Assaults" (2016), https://www.vice.com/en_uk/article/wd7945/i-froze-up-when-i-was-sexually-assaulted-and-weshould-stop-dismissing-that-response (accessed March 13, 2018).
} 
She then disclosed what she thought was the most shameful thing in her whole life: she had experienced orgasm during her sexual assault three years earlier...The word "no" doesn't seem to count. My own body didn't listen to it. So it's as if I never said it. ${ }^{56}$

In these accounts, we learn that being subjected to sexual violence involves a rupture between one's intentionality and one's bodily behaviour, or physical actuality. What she intends is resistance and flight from the scene, but her body "freezes" or "flops." There is psychological explanation for the freeze/flop response to trauma ${ }^{57}$, but there is ontological impact on one's being-in-the-world here as well. If being and appearance are one and the same, the victim who lies still in abuse, is the always-available body, the "living corpse," trussed-up and ready to be devoured. Even if there was an "invisible actor" in her head urging her to respond differently, or if she partakes in an inner plural dialogue that debates the best way to survive the situation (though actually her mind "drifted"), ${ }^{58}$ this has no bearing on her appearance in the scene. If we are our bodily appearance in the world, then the victim whose body responds to physical stimulation against her will ${ }^{59}$ bears the horror of this being cemented into a narrative of her life she has not initiated. Following from Arendt, we are supposed to be "seen, heard, touched, tasted and smelled," 60 and this is given meaning by the spectators to our appearance. Regardless of the victims' intended appearance and the very truth of her lack of consent, it is the perpetrator as witness to abuse who gives remembrance. As witness, the perpetrator disregards victims' intentionality, and cements victims' physical stillness, or orgasm as her appearance in that scene.

Victims of sexual violence might experience a fear of sex, pregnancy and motherhood post-rape; this demonstrates a clear social and psychological undermining of primary natality. I will present an ontological analysis of the undermining of primary natality, by looking at the sexual violence of forced pregnancy. The undermining of the primary appearance in the world (physical birth) is unique to sexual violence and so essential to an analysis of the harm of rape.

Schott analyses rape and forced pregnancy as a strategy of genocide, and her analysis uses the Arendtian framework of natality. How can the production of new beginners ever amount to genocide? Schott identifies five concepts that characterise natality, and also, she claims, mortality. First, change, or coming-into-being, second separation and difference, third, vulnerability, then plurality, and finally conflict. Schott introduces mortality in her framework because she claims that destruction and becoming are "inseparable moments" 61

\footnotetext{
${ }^{56}$ Matt Atkinson, 2011, "What if my body had a sexual response during rape?” (2011), http://www.survivormanual.com/what-if-my-body-had-a-sexual-response-during-rape (accessed March 13, 2018).

${ }^{57}$ In a psychotherapeutic response to sexual violence, Zoe Lodrick teaches five common responses to trauma, in addition to the commonly known fight or flight, she adds freeze, flop and friend as different survival strategies. This is known as the five Fs.

${ }^{58}$ In the five F s theory of trauma response, there is no mind/body duality where she is psychically active but bodily passive, rather her actions and thoughts freeze, flop etc

59 "Males can respond physically to stimulation (get an erection) even in traumatic or painful sexual situations. Therapists who work with sexual offenders know that one way a perpetrator can maintain secrecy is to label the child's sexual response as an indication of his willingness to participate. "You liked it, you wanted it," they'll say. Many survivors feel guilt and shame because they experienced physical arousal while being abused" http://www.survivorsmanchester.org.uk

${ }^{60}$ Hannah Arendt, The Life of the Mind, 19.

${ }^{61}$ Robin May Schott, "Natality and Destruction: Arendtian Reflections on War Rape," in Birth, Death, and Femininity: Philosophies of Embodiment, ed. Robin May Schott. (Bloomington: Indiana University
} 
and so cannot be distanced theoretically. By doing so, she creates a framework for analysing forced pregnancy as genocide ${ }^{62}$. Schott writes, "women possess graves in their vaginas;" 63 the primary natal moment, while a beginning, can be coupled with the final mortal moment. The birthing of new beginners, understood previously as the life force of being-in-theworld, is shown to be a destructive moment in the scene of rape in war.

Natality as the capacity for newness is understood as both "the source of our origin and the source of our possibilities" 64 and a source of "faith and hope." 65 When this hope in newness is violated, the whole promise of natality is undermined. Just as Arendt analysed the stripping away of selfhood in concentration camps, rape camps remove individuals from publicness and reduce them to bare endurance. To be public we must act, and so to be stripped of newness and acting capacity is to be thoroughly "un-public." Rape camps in war and forced pregnancy violate the powerful promise of newness normally contained in the primary natal moment of birthing a new beginner. The natal capacity of the women who are forced to give birth is appropriated, the bonds of the community are undermined, and the child born of war rape "indelibly bears the mark of her enemy." 6667 The abuse is not a singular moment; rather the trauma will have repercussions for the future of those individuals and their community. I add to Schott's analysis that the destructive power of forced pregnancy is also rooted in the physical entanglement apparent in (almost all) sexual violence. The perpetrator occupies the body of his victim forever and remains entangled to her, the body of the child, and social body of that community. The primary natal moment here becomes a powerless moment; the victim as living corpse is an object for endurance, birthing the grave of her, and her community's mortality. Put another way, "birth itself becomes a weapon of death." 6869

Schott claims that Arendt idealised natality, and that her own analysis importantly corresponds natality with mortality because, as we have seen, birth can be a destructive moment. Birth can kill, birth can separate individuals from one another and their community and the primary act of birth can be reduced to sheer endurance, stripped of any hopefulness. I disagree that Arendt idealised natality. As a theoretical framework, it does create optimism (the promise of newness, the unique capacity of every beginner) but equally vulnerability is a necessary outcome of natality. We are all not only physically vulnerable to pain and lack of care, but existentially vulnerable to the unknowability of our appearance and action. I agree with Schott though that the primary natal moment can be a destructive

Press, 2010), 27.

${ }^{62}$ Forced pregnancy not only occurs in war or genocidal rape but is also a strategy of domestic abuse, trapping women in abusive relationships via cycles of pregnancy and child rearing. The power of Schott's argument lies in her coupling birthing new beginners with the destruction of a community of people.

${ }^{63}$ Robin May Schott, "Natality and Destruction: Arendtian Reflections on War Rape", 28.

${ }^{64}$ Ibid., 56.

${ }^{65}$ Ibid., 55.

${ }^{66}$ Ibid., 63.

${ }^{67}$ It does not follow from this depiction of forced pregnancy in genocide that all children born from rape are unwanted and unloved by their mothers. Instead, Schott invites us to consider what is meant when the primary scene of newness is appropriated violently.

68 Ibid., 63 .

${ }^{69}$ Cavarero notes in Horrorism that Hobbes entangles the natal moment with death. According to Hobbes, the mother's destructive power over her child is always apparent in her singular ability to preserve the life of the child. We all have a "passion for one's own survival" (23) and the mother can end this survival not through intentional harm, but from the mere withdrawal of care. For Hobbes the natal moment is the first moment of the potential for horror. 
moment. This natal/mortal moment though is utterly unique to sexual violence, and emphasises the need to analyse its harm alone, distinct from other forms of violence.

\section{The Harm of Sexual Violence on Being-in-the-World-with-Others}

That we are all natal beginners necessitates that our being-in-the-world is characterised by others. Because of this conceptual connection, when sexual violence undermines natality, we see it also undermines plurality. I will explore what I call the "psychic entanglement" of victims and abusers that creates an illusion of complicity and intimacy, binding the victim to the abuser.

I have presented the horror of physical entanglement, but sexual violence also creates a psychic entanglement between abusers and their victims. Being and appearing are one and the same and so "I can flee appearance only into appearance." "What sort of appearance can the traumatised subject, whose world has been limited and selfhood objectified, flee into? It is the traumatic scene of her abuse, witnessed only by her abuser.

$\mathrm{Du}$ Toit writes that a reality is created in sexual violence that is common only to the victim and her abuser. This shared world is an unequal psychic space "in which the rapist exists as self-consciousness understood as being-for-self, and the victim exists only as inessential consciousness, in its working on the thing (her body)." ${ }^{\prime 71}$ The consequence for the victim of occupying this world, shared only with her abuser, is a sense of intimacy, the shame of which leads to secrecy. Du Toit does not give the horror of psychic entanglement significant weight in her analysis. I therefore will unpick further how the intertwining of a degrading psychic experience with the perpetrator of abuse is really essential to the breakdown of one's being-in-the-world-with-others.

When violence is sexual, perpetrators and victims become psychically entangled in a shared world that is characterised by the illusion of intimacy. ${ }^{72}$ Sexual violence is, in the majority of cases, a crime committed without external, or additional witness. If there is a witness to abuse, they are likely to be complicit in or part of the abuse (i.e. gang rape, forced prostitution). Victims of sexual violence have been forced to appear in a particular way, a way that is seen only by the abuser. He has pushed her to her very edge of endurance, and so can tell her, "I know you in ways no-one else does." We know that natal, public being-inthe-world hinges on being witnessed, as this witnessing gives meaning and who-ness to the events of our lives and is the sole route to remembrance. The perpetrator is the only one who can give testimony to what has been done to her, the only one who can tell her story and remember her in this scene. Perpetrators of sexual violence elevate themselves to the status of sole, and therefore, privileged, witness. Psychic entanglement consequently is twofold, victims and abusers become enmeshed because of the creation of a shared world witnessed only by them and because what is witnessed is the horror of the edge of endurance. This entanglement serves to keep victims victimised..$^{73}$

\footnotetext{
${ }^{70}$ Hannah Arendt, The Life of the Mind, 23.

${ }^{71}$ Louise Du Toit, $A$ Philosophical Investigation of Rape, 82.

72 The unique intimacy of abuse is further understood from a healthcare and psychology perspective in the theory of 'traumatic bonds', used in analysis of intimate partner violence. The strong emotions of love and hate or love and fear are wrongly placed in opposition to one another; in fact the strength of these emotions intertwines them, where they are felt as one and the same.

${ }^{73}$ Victims are vulnerable to repeat victimisation due to a number of factors, including the 'naturalising' of abuse apparent in psychic entanglement. Thapar-Björkert et al. write that victims of violence will view their abuse from the eyes of their dominating abuser, which naturalises the violence, giving it explanation, even inevitability. See "Exploring Symbolic Violence in the Everyday: Misrecognition, Condescension, Consent and Complicity" Feminist Review 112 (2016): pp.144-162,
} 
The illusion of shared intimacy between abusers and their victims leads to a sense of complicity; as if victims have played an active role in the abuse simply by being a part of that shared reality. This intimacy is an illusion for two reasons, the victim has been unable to assert herself in the shared world, forced to appear in ways unwilled by her. She has not had the freedom to assert intimacy, where she would have the agency to proclaim, "I want you to see me in this way". Instead, as we have seen by exploring the undermining of natality, she has been reduced to a "what." Additionally, the extent to which this reality is mutually understood between victim and abuser is limited because for the victim the abuse and its impact are not contained in any one moment. The trauma of abuse is temporally indeterminate, in that it is an experience, not an event. Raine describes being "set in stone" by her rape, defined by her victimhood long after the act of abuse. Where for the perpetrator the rape was a mere event, an event that ended, for his victim the abuse spills temporally outside of the moment. The abuse is felt, physically and emotionally long after the event is over and has consequences that are life-long ${ }^{74}$. Flashbacks to trauma are common among victims of abuse, where memories in the form of physical sensation, smell, hearing voices, play out as if contemporaneous. This can occur many years after the event of abuse, but the tangibility of the memory is no less clear. The victim really hears the voice of her abuser, she really feels the physical sensation of bodily entanglement, and she is really in the moment of horror again. While her abuser will have memory of the event, he does not experience traces of the event in the present. The "shared world" of abuse is not really shared.

\section{Conclusion}

The natal turn in philosophy compels us to philosophical encounter the very antithesis of natality's promise of new beginnings and relationality, that being sexual violence. Sexual violence uniquely undermines natality, dismantling creative beginnings and publicness and entangling victims with their abuser. But if the shared world of abuse is not really shared, there is optimism for victims to break away from the suffocating sense of complicity, to appear anew, to assert her narrative account of the trauma. Psychic entanglement is based on an illusion of intimacy that can be rejected. For Brison, the condition of plurality necessitates that we are not only vulnerable to coming undone when others inflict abuse upon us, but we are also capable of "being remade in connection with others." "75 Being-inthe-world-with-others remains an ontological necessity throughout any experience. There always remains hopefulness for the most traumatised subject to re-assert action and appearance. Victims of sexual violence are therefore faced with the task of asserting selfhood after this dehumanising process of objectification, entanglement and isolation from others. We are faced with the question, how can trauma survivors best assert being-inthe-world-with-others? Or, put another way, how can survivors best let themselves live and how can others let them live?

\footnotetext{
https://doi.og/10.1057/fr.2015.53 (accessed January 26, 2018).

${ }^{74}$ Flashbacks and recurrent memories are common to life after trauma. In their research into memory and childhood sexual abuse, MacIntosh et al discuss how memories of trauma emerge as flashbacks long after the event of the abuse. The participants describe flashbacks as "intrusions on their waking, conscious experience" (62). See "As Time Went On, I Just Forgot About It: Thematic Analysis of Spontaneous Disclosures of Recovered Memories of Childhood Sexual Abuse", Journal of Child Sexual Abuse 25 (1): https://tandfonline.com (accessed March 13, 2018)

${ }^{75}$ Susan Brison, Aftermath: Violence and the Remaking of the Self (Princeton: Princeton University Press, 2002), xi.
} 


\section{References}

Arendt, Hannah. The Human Condition. 2nd Ed. Chicago: University of Chicago Press, 1998. The Life of the Mind (Volumes 1 \& 2). London: Secker \& Warburg, 1978. Origins of Totalitarianism. Oxford: Benediction Classics, 2009.

Atkinson, Matt. 2011. "What if my body had a sexual response during rape?". http:/ / www.survivormanual.com/what-if-my-body-had-a-sexual-response-during-rape (Accessed March 13, 2018).

Bowen-Moore, Patricia. Hannah Arendt's Philosophy of Natality. New York: Springer, 1989.

Brison, Susan. Aftermath: Violence and the Remaking of the Self. Princeton: Princeton University Press, 2002.

Butler, Judith. Precarious Life. London: Verso, 2004.

Cahill, Ann. "Foucault, Rape and the Construction of the Feminine Body", Hypatia 15, no. 1 (2000): 43-63. http://doi.org/10.1111/j.1527-2001.2000.tb01079.x (accessed January 24, 2018).

Cavarero, Adriana. Horrorism: Naming Contemporary Violence. Translated by William McCuaig. New York: Colombia University Press, 2008. . In Spite of Plato: a Feminist Rewriting of Ancient Philosophy. Translated by Serena Anderlini-D’Onofrio \& Aine O'Healy. Cambridge: Polity Press, 1995. . Inclinations: A Critique of Rectitude. Translated by Adam Sitze \& Amanda Minervini. Stanford: Stanford University Press, 2016. Relating Narratives: Stories and Selfhood. Translated by Paul Kottman. London: Routledge, 2000.

Du Toit, Louise. A Philosophical Investigation of Rape: The Making and Unmaking of the Feminine Self. London: Routledge, 2009.

Enander, Viveka. "Why Does She Leave: The Leaving Process(es) of Battered Women", Health Care for Women International 29, no.3 (2008): pp. 200-226. https://doi.org/10.1080/07399330801913802 (accessed January 27, 2018).

Hong, Jackie. "Why Victims Freeze Up During Sexual Assaults" (2016). https://www.vice.com/en_uk/article/wd7945/i-froze-up-when-i-was-sexuallyassaulted-and-we-should-stop-dismissing-that-response (accessed March 13, 2018).

Lodrick, Zoe. "Psychological Trauma-What Every Trauma Worker Should Know" http://www.zoelodrick.co.uk/training/article-1 (accessed March 13, 2018).

MacIntosh, H, B, Fletcher, K, Collin-Vézina, D. “'As Time Went On, I Just Forgot About It": Thematic Analysis of Spontaneous Disclosures of Recovered Memories of Childhood Sexual Abuse, Journal of Child Sexual Abuse 25: 1 (2016): 56-72. http://www.tandfonline.com (Accessed March 13, 2018).

R M. Schott. 'Natality and Destruction: Arendtian Reflections on War Rape' in Birth, Death, and Femininity: Philosophies of Embodiment, ed. Robin May Schott, 49-69. Bloomington: Indiana University Press, 2010.

Stone, Alison. 'Natality and mortality: rethinking death with Cavarero', Continental Philosophy Review 43, no. 3 (2010): 353-372. https://doi.org/10.1007/s11007-010-9148-3 (accessed January 5, 2018).

Thapar-Björkert, Suruchi \& Samelius, Lotta \& Sanghera, Gurchathen. 'Exploring Symbolic Violence in the Everyday: Misrecognition, Condescension, Consent and Complicity' Feminist Review 112 (2016): 144-162. https://doi.og/10.1057/fr.2015.53 (accessed January 26, 2018). 